TILTAI, 2014, 3, 109-122, ISSN 1392-3137 (Print), ISSN 2351-6569 (Online)

\title{
KANITERAPIJOS UŽUOMAZGOS LIETUVOJE: VIENO ATVEJO STUDIJA
}

\author{
Brigita Kreivinienė, Natalia Zukhbaya, Laura Aširovienė \\ Klaipédos universitetas, Všl „Linksmosios pédutès“, \\ Klaipédos „,Medeinès “ mokykla
}

\begin{abstract}
Anotacija
Straipsnyje pristatomi pirmieji moksliniai bandomujų kaniterapijos užsièmimų duomenys Lietuvoje. Pristatoma kokybinè vieno atvejo studija, kur taikyti skirtingi tyrimo metodai: naratyvinè ir kontent (turinio) analizè. Atlikta ugdymo naratyvinè personalo (pedagogų ir psichologo) ir vaiko mamos atsiliepimų po kiekvieno kaniterapijos užsièmimo analizè. Mamos apklausos anketos analizè atskleidè, kad užsièmimai su šunimis lèmė lengvesnę vaiko adaptaciją mokykloje, pakito vaiko fiziniai parametrai (pagerejo apetitas, jis tapo aktyvesnis). Kaniterapijos stebėjimo protokolo analizė atskleidè, kad užsièmimai paskatino vaiko socialinę raidą ir kognityvinị pažinimą, tobulino jo kalbinę raišką. Emocinès būklès vertinimo skalè atskleidè, kad užsièmimai su šunimis teigiamai veikia vaiko emocinį pasaulị - teigiamos emocijos dominuoja visuose užsièmimuose.

PAGRINDINIAI ŽODŽIAI: kaniterapija, vaikai su negale, gyvenimo kokybè.
\end{abstract}

\begin{abstract}
The very first scientific data gathered in exploratory research of canine therapy in Lithuania is presented in the article. One case qualitative study is presented. Qualitative one case study was applied using different research methods: narrative and content analyses. Narrative analysis was used to analyze data gathered from educators, psychologist and mother of the child after each canine therapy session. Narrative interpretation was applied for canine therapy observation report, when each five minutes the changes of child were described. Report of canine therapy observation divulged that sessions were important for child's greater social development, verbal expression and cognitive development. Scale of emotional evaluation showed that canine therapy sessions have great importance in developing positive emotions.
\end{abstract}

KEY WORDS: canine therapy, children with disabilities, quality of life.

DOI: http://dx.doi.org/10.15181/tbb.v68i3.887

\section{Ivadas}

Pastaraisiais metais medicina ir specialusis ugdymas vis dažniau integruoja i savo turinį netradicinius metodus, kurie žmogų teigiamai veikia. Vienas šių metodų - gyvūnų terapija, kurios teigiama nauda žmogui mažai kas abejoja (Altschiller, 2011). Mokslo pasaulyje ịvairios gyvūnų terapijos pamažu atranda deramą vietą naujų žinių konstravimo procese ir praktiniame pagalbos klientui darbe (Ensminger, 2010). Medicinoje kaniterapija (dar vadinama terapija su šunimi) praktikuojama jau daugiau nei penkiasdešimt metų: teigiamas poveikis pacientams pastebėtas paliatyviosios slaugos namuose, psichiatrijos departamentuose ir ligoninèse (Ens- 
minger, 2010; Barker ir kt., 2010; Marcus, 2011). JAV ir Didžiosios Britanijos medicinos centruose jau tapo ịprasta praktika ịtraukti ị medikų ar specialiojo lavinimo specialistų komandą specialiai apmokytą dirbti terapinị darbą šuni (angl. a pet therapy dog) (Marcus, 2011). Užsienio šalių patirtis parodè, kad kaniterapiją taikant paliatyviosios slaugos namuose ženkliai pagerẻjo pacientų gyvenimo kokybė (Cipriani ir kt., 2013; Travers ir kt., 2013), o pacientams su demensija pagerejo dar ir nuotaika, psichosocialinis funkcionavimas (Travers ir kt., 2013), chroniškos šizofrenijos atveju sumažejo specifinių ir generalizuotų simptomų (Villalta-Gil ir kt., 2009). Kiti moksliniai tyrimai atskleidè (Barker ir kt., 2010; González-Ramírez ir kt., 2013), kad bendravimas su šunimi gali padèti žmogui išgyventi stresą, jis veikia kaip streso malšintojas. İvairios specialiojo ugdymo programos pagerino vaikų, turinčių įvairių sutrikimų, funkcionavimą (Altschiller, 2011): disleksijos, vaikų su cerebriniu paralyžiumi, autizmu ir kitais atvejais. Tyrimai atskleidè (Altschiller, 2011; Ensminger, 2010), kad pagerẻjimai buvo psichologinio (drąsa, atvirumas bendraujant, geresnis ryšys su bendraamžiais ir pan.) ir funkcinio (kalbos raida, geresnis fizinis funkcionavimas ir pan.) pobūdžio. Kitas panašus tyrimas atskleidè (Moore ir kt., 2013), kad skaitymas šalia gulinčio šuns gali pagerinti skaitymo gebejjimus, bet ne visada paties skaitančiojo požiūrị ị savo skaitymą.

Bandomieji kaniterapijos užsièmimai (jie kol kas oficialiai vadinami edukaciniais) Lietuvoje pradèti neseniai, dar jaučiamas formavimosi procesas, tikimès, kad ateityje Sveikatos apsaugos ministerija ịteisins tai kaip sveikatinimo programą. 2012 metais Sveikatos apsaugos ministrui patvirtinus delfinų terapiją kaip psichoemocinio ir fizinio lavinimo paslaugą, kuri priskirta sveikatinimo paslaugoms, imta dar intensyviau igyvendinti kaniterapijos plètros idẻją, nes sukurtas precedentas gyvūnus naudoti terapijai. Kaniterapijos mokslinès užuomazgos kilo Lietuvos sveikatos universiteto Edukacijos centre, kur jau daugeli metų rengiami profesionalūs kinologai, įkurta ir Kaniterapijos asociacija, kuri teoriškai ir praktiškai plètoja šią idejją.

Kaniterapijos plètrą Lietuvoje šiuo metu riboja keletas svarbių trikdžių. Visų pirma ji nėra reglamentuota, be to, trūksta mokslinių tyrimų. Nepaisant užsienio šalių patirties ir atliktų tyrimų, būtina kurti Lietuvoje veikiančiu kaniterapija užsiimančių organizacijų mokslines ir praktines bazes, bendradarbiavimo tinklus su mokslo institucijomis, taikyti tik patvirtintas metodikas, siekiant šiam gyvūnų terapijos metodui pelnyti deramą vietą Lietuvos sveikatos bei specialaus ugdymo sistemose. 2014 metais Lietuvos sveikatos ministerijai prièmus nutarimą dèl Lietuvos sveikos gyvensenos ir natūralios medicinos rūmų dalyvavimo išduodant tokių metodų, kai patys paslaugos teikejai vienas kitą kontroliuoja, taikymo licencijas, gyvūnų terapijos veikla turètų pagyvèti (Ketinimų protokolas, 2014) ir būtų iteisinta. 
Kitas kaniterapijos plètrą stabdantis veiksnys - netinkamas šuns vaidmens visuomenèje suvokimas (Altschiller, 2011). Dažnai manoma, kad šuo mūsų aplinkoje yra ịprastas gyvūnas, todèl jo įsigijimas jau savaime gali būti vadinamas „terapija“. Tuo tarpu šuns atrankos, dresavimo, darbo su juo metodikos parinkimo procesas nèra toks paprastas, kaip atrodo. Todèl būtų teisinga paminèti, kad terapijoje gali būti naudojamas ne kiekvienas šuo, kaip ir ne kiekvienas žmogus, turintis tinkamą kaniterapijai šuni, gali vesti šiuos užsiëmimus. Kaniterapijos taikymas - tai ne tik šuns savybių pažinimas, gebejjimas nuspèti nuotaikas, dresuoti ir pan., visų pirma tai veikla su žmonėmis, kurie turi sutrikimų. Tai reiškia, kad dirbama su pačia jautriausia visuomenès grupe, todèl būtina labai gerai išmanyti sutrikimus, gebèti parinkti tinkamą metodiką, numatyti užduotis, kelti realius tikslus, turèti tinkamas nuostatas neigaliujų atžvilgiu ir pan.

Dèl šiu priežasčių šis pirmasis mokslinis straipsnis kaniterapijos srityje ypač svarbus pradedant konstruoti kaniterapijos mokslinị diskursą Lietuvoje.

Šio straipsnio tikslas - pristatyti pirmuosius mokslinius bandomųų kaniterapijos užsièmimų Lietuvoje duomenis.

\section{Tyrimo metodika}

Kokybinè vieno atvejo studija, taikant skirtingus tyrimo metodus: naratyvinę ir kontent (turinio) analizę. Tyrimo metu atlikta ugdymo personalo (pedagogų ir psichologo) ir vaiko mamos atsiliepimų po kiekvieno kaniterapijos užsièmimo naratyvinè analizè. Atlikta dešimties kaniterapijos stebejjimo užsièmimų protokolo analizė (aprašant vaiko pokyčius kas penkias minutes) naratyvinę analizę pritaikant duomenims interpretuoti. Skaitlinė kontent (turinio) analizė taikyta apdorojant psichologų sudarytą vaiko emocinès būsenos skalę. Naratyvinė analizė (Howarth, 2000) atlikta paliekant ilgesnes frazes, žodžių junginius (Riessman, Quinney, 2005; Mariampolski, 2001), kad būtų galima suprasti esminius pokyčius, nurodytus respondentų. Objektyvaus stebejjimo metodo rezultatai pristatomi taikant aprašomaji (deskriptyvinị) metodą (Elo, Kyngäs, 2008; Henwood, Pidgeon, 1994), subjektyvūs mamos ir pedagogų pastebejjimai analizuojami straipsnyje iliustruojant ilgesnèmis frazėmis ir žodžiu junginiais, kurie atkuria situacijos autentiškumą (Elo, Kyngäs, 2008; Mayring, 2007; Onwuegbuzie, Leech, 2006; Bidgood ir kt., 2003).

Vieno atvejo studija atlikta Klaipėdos „Medeinès“ mokykloje. Všt „Linksmosios pėdutès" psichologas, taikydamas iš anksto parengtą metodiką, bendradarbiaudamas su Klaipėdos universiteto mokslininkais vedė dešimt užsièmimų su trimis arba keturiais šunimis. Metodika parengta vienam konkrečiam vaikui, turinčiam 
Dauno sindromą. Vaiko amžius - 10 metų. Tyrimas vyko nuo 2013 metų rugsėjo 26 dienos iki 2014 metų vasario mėnesio. Atliekant tyrimą vykdyti struktūruoti susitikimai su trimis arba keturiais šunimis, siekiant konkretaus tikslo. Iš anksto nutarta rinkti subjektyvius pastebėjimus iš vaiko tėvų, pedagogų. Visus užsièmimus stebėjo institucijos psichologas, taikant stebejjimo metodą fiksuotos vaiko emocinès reakcijos, suskaidžius viso užsièmimo trukmę (30 min.) kas penkias minutes.

Po kaniterapijos užsièmimų surinkti moksliniai duomenys, kurie analizuojami šiame straipsnyje: subjektyvūs mamos pastebẻjimai, pedagogų nuomonès, objektyvaus stebejjimo protokolas.

\section{Vaiko su negalia psichosocialinès situacijos vertinimas}

Surinkta anamnezė prieš pradedant užsièmimus su šunimis atskleidè, kad tyrimo dalyvei diagnozuotas Dauno sindromas ir jị lydinčios problemos: sulètejjusi psichinė ir kalbos raida, kalbos ir komunikacijos sutrikimas, protinis sutrikimas. Pedagoginès psichologinès tarnybos (PPT) pažymoje rašyta, kad mergaitei buvo sunku nusėdèti, išklausyti instrukcijas, jas suvokti ir vykdyti. Ji buvo labiau linkusi veikti pagal nurodymus, reikejo nuolatinès pagalbos. Nustatyta, kad bendrieji gebejjimai atitinka labai žemą intelektinių gebejjimų lygị. Buvo sunku išskirti mergaitès galias, nes visų PPT ịvertinimų rezultatas atitinka labai žemą mokymosi lygị. Specialiojo pedagogo išvadose pažymėta, kad „mergaite žino savo vardą, amžių. Kalba sunkiai." Papildomos problemos, kurias paminėjo mergaitès mama: neišsivysčiusi verbalinė kalba (mergaite retai tardavo pavienius žodžius), Dauno sindromui būdingas liežuvio iškišimas, socialinè izoliacija (mergaitẻ nebendravo, buvo uždara, klasės aplinkoje jos niekas nepastebėdavo, bendravo tik su viena drauge, su kuria per pamokas ir pertraukas piešdavo). Mergaitei perejus ị trečią klasę pasikeitè mokytoja, situacija beveik nepakito: mergaitè buvo socialiai užsiangažavusi, bijojo išsireikšti, kalbèti, kalbinama arba tylejjo, arba linktelèdavo galva.

Prieš bendravimo su šunimis užsièmimus mergaitès mama pasakojo, kad, pakeitus ịprastą darželio aplinką, jai sunku adaptuotis mokykloje, net po dvejų metų nepriprato ir mokyklą lanko nenoriai.

\section{Tyrimo rezultatų apžvalga}

Ugdymo personalo atsiliepimų vertinimas. Šie vertinimai rinkti po kiekvieno užsièmimo, mokyklos psichologei neformaliu būdu apklausiant ugdymo personalą, kuris dirbo su mergaite. Visos pastabos buvo užrašomos atsiliepimų lapuose, vèliau struktūruojamos ir analizuojamos taikant naratyvinę analizę. 
Analizė atskleidè, kad ugdymo personalo atsiliepimus apie mergaitès būklę galima susisteminti ị tris pagrindines minimų pokyčių kategorijas:

- Emocinè raiška. Vertinant mergaitès bendrą psichologinę, socialinę ir emocinę būklę, ugdymo personalo nuomone, jai pradẻjus lankyti užsièmimus su šunimis, ji tapo atviresnè aplinkai, ,pagerèjo bendra emocinè būsena“, „mergaitė kur kas dažniau šypsosi“. Pedagogai pastebèjo: jei mergaitė ị ịstaigą ateidavo prastai nusiteikusi, liūdna, pasiteiravus jos apie užsièmimus su šunimis, ,nuotaika ženkliai pagerejja“, ,pasikeičia jos veidas“.

- Kalbinès raidos raiška. Tai, pedagogų vertinimu, buvo esminis pokytis, pastebėtas po užsièmimų su šunimis. Anksčiau mergaitẻ labiau naudodavo gestų kalbą ar pasyvų atsako tipą, o po užsiėmimo jos kalba pasikeisdavo: „paklausus mergaitė noriai atsako ị klausimus“ žodžiu, noriai bendrauja, tapo aktyvesnè mokyklos bendruomenèje, anksčiau nepastebètos loginès sąsajos, o po seansų suaktyvejjo mergaitès kognityvinès funkcijos: ịvardija raudoną spalvą ir ją sąmoningai išskiria iš kitų (anksčiau neskirdavo nei vienos spalvos). Be to, pradejo formuotis supratimas mažas-didelis, nes užsièmimuose vyravo šie palyginimai.

- Socialinès elgsenos pokyčiai. Socialinès elgsenos pokyčiai, pedagogų nuomone, sietini su kitais pasiekimais, kurie vystyti vienu metu (emocine raiška ir kalbine raiška). Po užsièmimų pedagogai pastebejjo ryškius pokyčius mergaitès socialiniame gyvenime: iš socialiai izoliuotos ir užangažuotos ji pamažu tapo savimi pasitikinčia. Mergaite igavo daugiau drąsos, socialinių igūdžių, èmé imituoti kitų elgesio modelius, pradẻjo suprasti ir taikyti socialinio etiketo taisykles: „sveikinasi per atstumą“, „pamoja ranka einant pro šalị“, ,atsisveikina“, „tapo daug žvalesnè, judresnë“, „turi daugiau draugü“. Pasikeitè mergaitès aktyvumas klaseje, ji mieliau dalyvauja pokalbiuose, pati imasi iniciatyvos pasakoti apie šunis.

Mamos atsiliepimų vertinimas. Mokyklos psichologė po kiekvieno užsiëmimo, kitą dieną, bendraudavo su vaiko mama ir žymėdavo visus jos išsakytus pastebejjimus apie vaiko pokyčius. Po visų užsièmimų mamos paprašyta užpildyti grịžtamojo ryšio anketą, kur pateikti atvirieji klausimai apie pastebètus pokyčius dalyvaujant užsièmimuose. Visa ši medžiaga analizuota taikant naratyvinị analizès metodą.

Atlikus surinktos medžiagos analizę, duomenys susisteminti ir išskirtos trys pokyčius apibrèžiančios kategorijos.

Motyvacijos kaita. Ši kategorija išskirta vertinant mamos pasisakymus apie tai, kad pradejus lankyti seansus su šunimis, mergaitès motyvacinė elgsena gerokai pakito. Rytais, kai mergaitei teko keltis ị mokyklą, ji tai darydavo nenoriai, o ma- 
mai priminus, kad vyks seansas su šunimis, nuotaika iš karto pagerèdavo, mergaitė greitai susiruošdavo ir išskubẻdavo ị mokyklą. Po seanso su šunimis grįžusi namo, mergaite stengdavosi atkartoti užsièmimų turinị ir namuose „dresuodavo katiną““. Vèliau kasryt keldamasi ị mokyklą klausdavo, ,ar bus šuniukai“, jų ypač laukdavo. Mamos teigimu, mergaitė „pradèjo gražiau elgtis su jų augintiniu katinu, jo nebeskriaudžia, nebekankina“, „savo elgesị su šunimis perkèlè ị elgesị su katinu, todèl jo nebevežioja vežimėlyje“, „mergaitei pagerèjo apetitas, lengviau keliasi rytais“.

Kognityvinis vystymasis. Tik prasidëjus pirmiesiems užsièmimams su šunimis, ryškiai pagerejjo vaiko kalbinė raiška ir ekspresija. Mamos teigimu, mergaitė niekada taip nesielgdavo savo iniciatyva: po užsièmimų pati prieidavo ir imdavo pasakoti apie šunis. Mamos nuomone, anksčiau ,ji taip nesielgdavo, o grįždavo iš mokyklos namo ir nenoriai atsakinèdavo pavieniais žodžiais“. Pakito ir kūno, socialinių igūdžiu supratimas. Anksčiau nemėgo ritualų - pasirengimo mokyklai, kèlimosi, nesileisdavo šukuojama. Po pirmo seanso su šunimis ji jau kitą rytą „leidosi surišama plaukus, nekantriai laukè susitikimo su šunimis“, be to, ,palengvejo atsikèlimas, pasiruošimas, higienos ịūdžiai, savitvarka“. Pradèjo skirti spalvas: raudoną, geltoną, mèlyną, žalią.

Socialinès elgsenos pokyčiai. Mamos vertinimu, socialinès elgsenos pokyčiai - bene didžiausias pasiekimas po užsièmimų su šunimis. Anksčiau mergaitę lydèjo „baimé per didelio dėmesio“, ji „staiga pribėgus šnekinama nekalbėdavo“, „nemokejjo atsisakyti veiklos, kuri jai nepatinka“ ir kt. Tik pradejjus lankyti užsièmimus pirmiausia pasikeitè mergaitès elgesys, emocijos, nenoras eiti ị mokyklą virto „švytejjimu“ ir „,bègimu į mokyklą“. Mamos nuomone, iš karto pastebèta, kad pakito vaiko „drąsos“ būsena: ji tapo atviresnè, aktyvesnè bendraudama, ypač tai atsiskleidè nepažịstamų žmonių draugijoje: „Net pašnekinta nepažįstamų žmonių ji mielai atsako“, išryškejjo socialinis humoro jausmas - „moka pajuokauti““.

Užsièmimų stebèjimo ir emocinès būsenos vertinimas. Objektyvaus stebejjimo metodo rezultatai (dešimties kaniterapijos stebejjimo užsièmimų protokolo analizè) ir vaiko emocinès būsenos skalès analizė pristatomi taikant aprašomaji (deskriptyvinị) kontent analizès metodą.

Užsiẻmimų stebẻjimo ir emocinès būsenos vertinimo rezultatų analizė atskleidè, kad psichologo stebejjimus apie mergaitès būklę galima susisteminti ị tris pagrindines pokyčių kategorijas: emocinè būklè, kognityvinès funkcijos, socialinès elgsenos pokyčiai.

Kaniterapijos seansų metu stebèta vaiko emocinè būsena. Kadangi mergaitè pati negalëjo įvardyti savo jausmų, iš anksto nuspręsta sudaryti skalę, kuri atskleistų vaiko emocinę būseną. Skalè sudaryta tyrime dalyvavusių psichologių, remiantis tradiciniu emocijų skirstymu ir tikètina vaiko elgesio reakcija ị dirgiklius. Emocinè būsena vertinta penkių minučių atkarpomis. Jei nors kartą pasireiškẻ bent 
vienas iš skalèje nustatytų požymių, žymèti įverčiu balai. Papildomai objektyvaus stebejjimo protokole kas penkias minutes rašyta viskas, kas stebėta vaiko, dalyvaujančio kaniterapijoje, išraiškoje (kalba, socialinis kontaktas, veiksmai, emocinès išraiškos, etc.).

Skalès, matuojančios vaiko emocinès būsenos lygị, matavimo vienetai:

1 - agresija, saviagresija, isterija, prieštaravimas, verkimas;

2 - nedalyvavimas, atsisakymas;

3 - apatiškumas, neaktyvumas, nenoras ịsitraukti ị veiklą;

4 - vykdo užduotis, tačiau nerodo iniciatyvos;

5 - šypsosi, noriai vykdo užduotis;

6 - garsiai juokiasi, žaidžia.

Šioje skalejje kas penkias minutes vertinta vaiko emocinè būklè (balais), kiekvienas užsiëmimas - šių balų skaitlinė suma, kurios didžiausias ịvertis galèjo būti 36 balai.

Emocinè būklè. Susisteminus gautus duomenis, gauta vaiko emocinès būsenos kreivè (žr. 1 paveikslą).

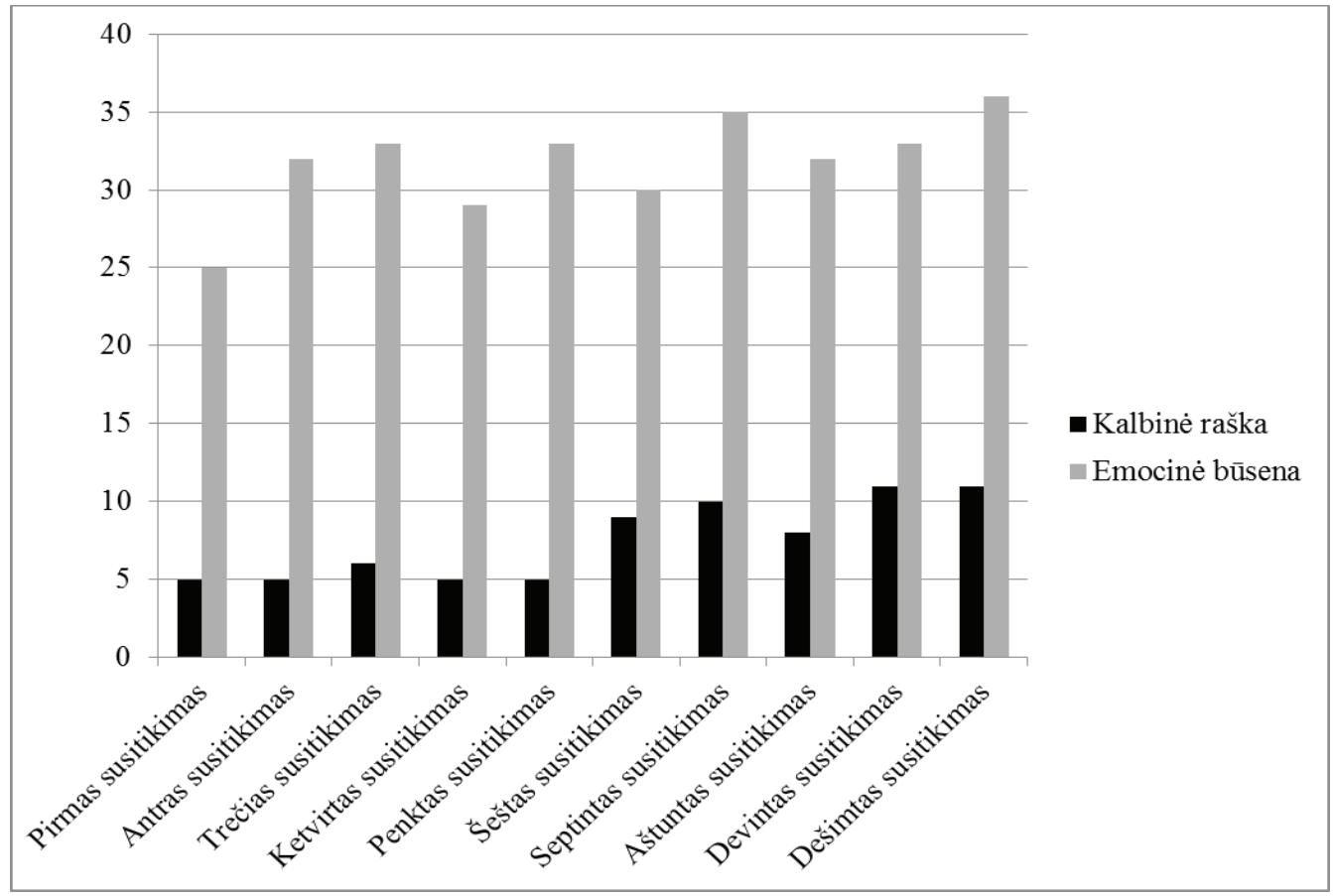

1 pav. Vaiko emocinès būsenos ir kalbos raiškos skale dešimties kaniterapijos užsièmimų metu 
Skalè atskleidžia, kad vaiko emocinè būsena nuolat gerèjo, esant nedideliems nuokrypiams, bendraja prasme galima teigti, kad vaiko emocinè būklè gerẻjo. Pirmo susitikimo metu surinkti 25 emocinio vaiko vertinimo balai, ši skaitlinè išraiška didesnè už vidurkị. Pirmo užsièmimo metu iškeltas tikslas - formuoti vaiko saugų aplinkos supratimą ir užmegzti teigiamą emocinị ryšị su užsiẻmime dalyvaujančiais šunimis bei psichologu. Pastebėta, kad teigiamas emocinis fonas per pirmą užsièmimą veikè ir kitus užsièmimus. Per paskutinį užsièmimą mergaitė jautėsi ypač atsipalaidavusi ir rami, surinktas maksimalus balų skaičius. Išanalizavus gautus duomenis, ịvertinus uždarą vaiko būdą, kai sunku užmegzti kontaktą su nepažĭstamais žmonėmis, galima daryti prielaidą, kad užsimezge stiprus ryšys tarp vaiko ir šunų. Kaniterapijos seansų metu stipriai sužadintos teigiamos mergaitės emocijos. Pastebėta, kad per pirmą, ketvirtą ir aštuntą užsièmimus mergaite išreiškè, kad šiek tiek baiminasi garsaus šunų lojimo. Tačiau ši būsena greitai liaudavosi, mergaitei pastebèjus, kad šuo rodo draugiškumą. Baimingumas pasireikšdavo tik dèl netikèto lojimo.

Kognityvinès funkcijos. Kognityvinių funkcijų kategorijose išskirtos trys pakategorès: atmintis, akademiniai gebejjimai, kalbinès raidos raiška. Šios trys pakategorès detaliau aptariamos.

- Atmintis. Per pirmuosius tris užsièmimus mergaitė negalèjo prisiminti nei vieno šuns vardo, tuo tarpu per ketvirtą ir penktą užsièmimus jau pastebėta, kad mėgina kartoti ir ịsiminti šuns vardus, teisingai ịsiminė vieno. Tačiau nuo šešto užsièmimo mergaitė lengvai pradejjo skirti visus keturis šunis ir puikiai ịsiminè jų vardus, galèjo juos atkartoti. Taip pat nuo šešto užsièmimo pastebèta, kad šunų vardus pasako be suklydimų. Paskutinio užsièmimo metu mergaitei buvo parodyta nuotrauka su keturiais kaniterapijoje dalyvavusiais šunų atvaizdais. Mergaitė teisingai nuotraukoje ìvardijo visų jų vardus. Galima teigti, kad po penkių užsièmimų mergaitė ịsisąmonino šią informaciją.

- Akademiniai gebejjimai. Mamos prašymu per užsièmimus mergaitė mokyta skirti spalvas. Ši užduotis suformuota tik nuo šešto užsièmimo. Per ši užsièmimą mergaitès ėmus klausinèti spalvų, ji kartodavo „nežinau“. „Metonas“ - taip vadino ir raudoną, ir geltoną spalvas. Per aštuntą užsièmimą teisingai ịvardijo „oranžinę“" spalvą, vèliau - ir „,raudoną“, stengèsi ištarti ,"“" garsą. Skaičiuoti buvo sunku. Visada suskaičiuodavo iki triju (nuo penkto susitikimo), toliau nenuosekliai vardydavo ịvairius kitus skaičius.

- Kalbinès raidos raiška. Pastebėta, kad mergaite per užsièmimus buvo labai susikaupusi, atidi, susidomėjusi, nerode jokio streso. Manoma, kad tokia teigiama aplinka paskatino mergaitę labiau save išreikšti verbaline kalbos 
forma, rodyti iniciatyvą bendraujant, išsakyti savo norus ir pageidavimus. Pirmuosius penkis užsièmimus dažniau tiesiog atkartodavo psichologès sakomus žodžius: „Sėsk, geras šuo, duok, dèk ant žemès.“ Retai spontaniškai kalbėdavo, dažniausiai turinys buvo emocinis - „myliu Dūdą“. Pagal emocinio vertinimo skalę (žr. 1 pav.) iki šešto užsièmimo per kiekvieną užsièmimą surinkti maksimalūs penki balai, nuo šešto - stebẻtas ryškus pokytis. Po moksleivių atostogų mergaitė daug intensyviau reiškẻ savo norus, prašymus, o nežinodama, kaip kažką atlikti, klausdavo: „Kur segti? Čia. Einam. Šuniukai. Nenoriu, palauk. Eisiu su Dūda.“ Nuo šešto užsièmimo stebèta kur kas aktyvesnè kalbinè raiška: siekẻ devynis vienuolika balų iš dvylikos galimų.

Socialinès elgsenos pokyčiai. Per pirmą užsièmimą mergaitė nesuprato, kaip užmegzti kontaktą, ką daryti, kaip bendrauti. Buvo pasimetusi. Prasidejjus pirmam kaniterapijos užsièmimui, pirmąsias penkias minutes mergaitė nekalbèjo, stebèjo aplinką. Tada labai greitai užmezge kontaktą su šunimis ir pradẻjo tarti žodžius, pasakytus psichologès. Jau per pirmą užsièmimą mergaitè pradèjo šypsotis ir kalbẻti savo žodžius - ne tik kartoti (pvz.: „myliu Dūdą“). Baigiantis užsièmimui mergaitei buvo sunku išsiskirti. Per kitus užsièmimus visada pati pasisveikindavo: „Labas“, ir atsisveikindavo su visais. Bendravimas su šunimis jai padejo suprasti, kad su gyvūnais reikia elgtis švelniai ir atsargiai. Per pirmuosius susitikimus mergaitė vis stipriai tempdavo pavadelį, mokoma švelnumo ir atidumo gyvūnui nuo ketvirto užsièmimo pradèjo su šunimis elgtis švelniau. Ji tapo švelnesnè ir atidesnė šunų poreikiams, nebetempé pavadžio, pakviesdavo žodžiu: „Einam, Nordai.“ Per užsiëmimus pastebèta, kad mergaitė išreiškẻ savo savarankiškumą: sakydavo, ką nori veikti, kur vykdyti veiklą, pvz., „eisiu su Dūda“; ,nenoriu“.

\section{Tyrimo rezultatų sąsaja su kitomis mokslinėmis studijomis}

Ši pirmoji Lietuvoje kaniterapijos užsièmimų atvejo studija atskleidè, kad terapija naudojant šuni yra reikšminga tiek vaiko, tiek ir jo artimosios aplinkos gyvenimo kokybės parametrams: kinta vaiko socialinė elgsena, kognityvinès funkcijos, psichoemocinẻ būklè, motyvacija ir pan. Aprašytos mokslinės studijos (Altschiller, 2011; Marcus, 2011; Villalta-Gil ir kt., 2009; Griess, 2011) atskleidè, kad bendravimas su šunimi turi kelias terapines funkcijas: palaikomas didesnis fizinis aktyvumas, geresnè ilgalaikès veiklos motyvacija (pvz., priežiūros, vedžiojimo ir pan.), palengvejja sunkūs negalės simptomai. Moksliškai ịrodyta, kad ta pati 
veikla (pavyzdžiu, skaitymas) gali tapti kur kas malonesnè, jei i ją įsitraukia ir šuo (Altschiller, 2011; Marcus, 2011; Griess, 2011).

Analizuojant tyrimo rezultatus, galima teigti, kad panašūs rezultatai gauti ir užsienio autorių atliktuose tyrimuose, nors tyrimai vykdyti su kitokio pobūdžio sutrikimų turinčiais žmonėmis. Pavyzdžiui, užfiksuoti motyvacijos ir socialinės funkcijos pakitimai buvo panašūs kaip ir kitose mokslinèse studijose (Altschiller, 2011; Barker ir kt., 2010; Lotan, Merrick, 2011): įrodyta, kad šuo terapijoje naudojamas kaip stiprus motyvuotojas, skatinantis veikti, inicijuoti, pastebėta, kad po seansų vaikai kur kas smalsesni - siekia pažinti socialinès aplinkos kontekstą, aktyvesnè jų socialinio bendravimo raiška. Šioje ir kitose studijoje aprašoma, kad vaikai kur kas mieliau tęsia sudètingesnę nei ịprastai veiklą, jei užsièmime dalyvauja šuo (Altschiller, 2011; Lotan, Merrick, 2011). Chroniškos negalios atveju (pvz., demensija) šuns naudojimas terapijai net gali padèti iš dalies įveikti nuolatinio apatiškumo būseną (Motomura ir kt., 2004). Taigi analizuojamu atveju rezultatai nebuvo netikèti: mergaitės motyvacija eiti ị mokyklą ryškiai pasikeisdavo, jei ryte keliantis mama pasakydavo, kad tą dieną vyks užsièmimai su šunimis. Šio tyrimo rezultatai, kai išryškejjo socialinès elgsenos pokyčiai ir drąsa, patvirtina ir kitų autorių atlikti panašūs tyrimai (Altschiller, 2011; Villalta-Gil ir kt., 2009; Kovacs ir kt., 2006). Ankstyvosios kaniterapijos mokslinès studijos (1994 m. JAV) daugiausia nukreiptos ị bendravimą su terapiniu šunimi kaip stigmos švelninimą proto negalios ir elgesio sutrikimų turintiems žmonėms (Ritchie, Amaker, 2012), nes šuo bendrauja nuoširdžiai, neturi išankstinių nuostatų. Po kaniterapijos pakitusi socialinė elgsena aiškinama artimu fiziniu kontaktu su šunimis (Kovacs ir kt., 2006). Kitaip tariant, kuo glaudesnis socialinis ryšys su terapiniu šunimi, tuo daugiau vaikas išreiškia teigiamų emocijų, kinta socialinès akceptacijos parametrai (vaikas socialinès aplinkos nebesuvokia kaip grèsmès). Dažnai stebėti emocijų pliūpsniai: „Myliu Dūdą“ ir pan., tai rodo fizinio kontakto ir emocijų sąsajas su socialine sfera. Pedagogai, vertindami mergaitès socialini pokyti, nuolat minèjo jos išaugusį pasitikèjimą savimi ir aplinka: pati pasilabina, pamojuoja, ko anksčiau nebūdavo. Su šunimis, vèliau ir namie su katinu mergaitè ilgainiui ėmė elgtis ne kaip su žaislu, o kaip su socialiniu partneriu.

Analizuojant socialinius pokyčius pastebèta, kad net ir nekalbančio žmogaus gestikuliavimas tampa aktyvesnis, o verbalinę kalbą taikantys žmonès, pastebèta, lengviau ėmè palaikyti (kontroliuoti) pokalbị su kitu pašnekovu (Kovacs ir kt., 2006), be to, po užsièmimų žmonès apibūdinami kaip geriau funkcionuojantys bendruomenèje (Villalta-Gil ir kt., 2009). Užfiksuota, kad pasikeitė ir žmogaus fizinio aktyvumo būsena (Altschiller, 2011; Lotan, Merrick, 2011; Kovacs ir kt., 2006). Pedagogai, vertindami mergaitès fizini aktyvumą, pabrēžè, kad ji tapo judresnè, aktyvesnè. 
Mokslinès kaniterapijos studijos (Altschiller, 2011; Villalta-Gil ir kt., 2009; Kovacs ir kt., 2006; Mills, Yeager, 2012) atskleide, kad tam tikrais atvejais kaniterapijos užsièmimai yra svarbūs ne dèl akademinių pasiekimų, o emocinio palaikymo ir paramos požiūriu: šuo yra šalia kaip socialinis partneris, todèl fiksuojami dalyvio emociniai pokyčiai. Atvejo studija atskleide, kad mergaitès emocijos ryškiai pakito: tai atskleidè tiek subjektyvūs mamos, pedagogų, tiek ir objektyvaus stebejjimo protokolas bei emocijų vertinimas. Mergaitè šioje aplinkoje nebijojo išreikšti savo poreikių ir išsakyti savo nuomonès dèl siūlomos veiklos (mergaitė drąsiai èmè reikšti, nori užsiimti tam tikra veikla ar ne).

Kalbinès raiškos ir kognityvinių funkcijų vystymasis, užfiksuotas šioje atvejo studijoje, nenaujas ir užsienio šaliu tyrinejimuose (Altschiller, 2011; Carminati ir kt., 2013; Berry ir kt., 2013), stebimas ir emocinio atsipalaidavimo, streso malšinimo bei didesnio psichologinio patogumo tarpusavio ryšys, tai leidžia vaikui lavintis šias funkcijas.

\section{Išvados}

1. Šiandieniné specialiosios pagalbos vaikams su negalia sistema yra kur kas atviresnè ịvairiems netradiciniams ugdymo metodams, todèl kaniterapija galètų užimti deramą vietą ugdymo procese. Užsienio šalių patirtis ịrodè teigiamą šuns, kaip socialinio partnerio, naudą, kai jis ịtraukiamas ị gydymo ar ugdymo procesą (Altschiller, 2011; Lotan, Merrick, 2011; Kovacs ir kt., 2006; Berry ir kt., 2013). Šuo geba reaguoti ị žmogaus poreikius, nuotaikas, užtikrina teigiamą atmosferą, veikia raminamai ir padeda sukurti atpalaiduojančią aplinką (Berry ir kt., 2013). Net sudètingu streso ịveikos atveju šuo gali pagerinti žmogaus atsparumo mechanizmus, jis vadinamas „,sielos gydytoju“ (Carminati ir kt., 2013; Berry ir kt., 2013; Beck ir kt., 2012). Vieno atvejo studija atskleide, kad vaiko su Dauno sindromu emocinè būklè, kognityvinès funkcijos, socialinè elgsena, motyvacija, kalbinès raidos raiška pakito (daugiau ar mažiau). Mergaitè, kuri anksčiau buvo nedrąsi savo mokyklos aplinkoje, po kaniterapijos užsièmimų išdrąsèjo, pradejo reikšti savo norus, poreikius, išmoko atsisakyti jai neįdomios veiklos, ịsiminè šunų vardus, pradejjo skirti kelias spalvas, skaičiuoti. Galima teigti, kad toks psichosocialinis ir emocinis mergaitės pagerèjimas lëmé ir geresnę vaiko bei jo šeimos gyvenimo kokybę.

2. Ši pirmoji kaniterapijos studija empiriniu požiūriu yra pernelyg siaura, kad būtų galima atlikti generalizuotus apibendrinimus. Pastaruoju metu sparčiai besivystanti kaniterapijos reglamentavimo ir mokslinès plètros veikla 


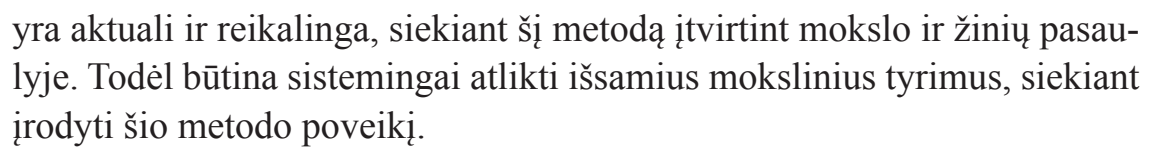

Gauta 20140710

Pasirašyta spaudai 20140929

\section{Literatūra}

Altschiller, D. (2011). Animal-Assisted Therapy. Oxford: Greenwoon, England.

Barker, S. B., Knisely, J. S., McCain, N. L. ir kt. (2010). Exploratory Study of Stress-Buffering Response Patterns from Interaction with a Therapy Dog. Anthrozoos 23(1): 79-91.

Beck, Ch. E., Gonzales, F., Sells, C. H. ir kt. (2012). The Effects of Animal-Assisted Therapy on Wounded Warriors in an Occupational Therapy Life Skills Program. The Army Medical Department Journal, April-June: $38-45$.

Berry, A., Borgi, M., Francia, N. ir kt. (2013). Use of Assistance and Therapy Dogs for Children with Autism Spectrum Disorders: A Critical Review of the Current Evidence. The Army Medical Department Journal 19 (2): 73-80.

Bidgood, B., Holosko, M. J., Taylor, L. E. (2003). A New Working Defi nition of Social Work Practice: A Turtle's View. Research on Social Work Practice. Sage Publications: London. Thousand Oaks 13 (3): 400-408.

Carminati, G. G., Lehotkay, R., Martin, F., Carminati, F. (2013). An Hypothesis about Jung's Collective Unconscious and Animal-assisted Therapy. NeuroQuantology 11(3): 451-465.

Cipriani, J., Cooper, M., DiGiovanni, N. M. ir kt. (2013). Dog-Assisted Therapy for Residents of Long-Term Care Facilities: An Evidence-Based Review with Implications for Occupational Therapy. Physical \& Occupational Therapy in Geriatrics 31(3): 214-240.

Elo, S., Kyngäs, H. (2008). The qualitative content analysis process. Journal of Advanced Nursing 62(1): 107115 .

Ensminger, J. J. (2010). Service and Therapy Dogs in American Society: Science, Law and the Evolution of Canine Caregivers. USA: Springfield, III: Charles C. Thomas.

González-Ramírez, M. T., Ortiz-Jiménez, X. A., Landero-Hernández, R. (2013). The Role of Stress of Therapy Dog Handlers in Animal-Assisted Therapy. Ansiedad y Estrés 19(1): 1-10.

Griess, J. O. (2011). A canine audience: The effect of Animal-Assisted Therapy on reading progress among students identified with learning disabilities. Doctoral thesis on Special Education. USA: Florida.

Henwood, K., Pidgeon, N. (1994). Beyond the Qualitative Paradigm: A Framework for Introducing Diversity within Qualitative Psychology. Journal of Community \& Applied Social Psychology 4: 225-238.

Howarth, D. (2000). Discourse. Forum: Qualitative Researcher 3(2): Art. 6.

Ketinimu protokolas „,Dèl Valstybès sankcionuoto natūraliosios medicinos ir sveikos gyvensenos savireguliavimo funkcijos perdavimo Lietuvos sveikos gyvensenos ir natüraliosios medicinos rümams “. $2014 \mathrm{~m}$. sausio $10 \mathrm{~d}$. Prieiga internete: www.sveikatosrumai.lt [žiūrèta 201403 11].

Kovacs, Z., Bulucz, J., Kis, R., Simon. L. (2006). An Exploratory Study of the Effect of Animal Assisted Therapy on Nonverbal Communication in Three Schizophrenic Patients. Anthrozoos 19(4): 353-364.

Lotan, M., Merrick, J. (2011). Rett Syndrome: Therapeutic Interventions. Hauppauge, N.Y.: Nova Science.

Mayring, Ph. (2007). On Generalization in Qualitatively Oriented Research. Forum: Qualitative Social Research 8(3): Art. 26.

Marcus, D. A. (2011). The Power of Wagging Tails: A Doctor's Guide to Dog Therapy and Healing. New York: Demos Medical Pub.

Mariampolski, H. (2001). Qualitative Market Research: a Comprehensive Guide. SAGE publications: Thousand Oaks, London, New Delhi.

Mills, J. T., Yeager, A. F. (2012). Definitions of Animals Used in Healthcare Settings. The Army Medical Department Journal, April-June: 12-17.

Moore, E. G. J., Hlava, T., Garcia, S. L., Brem, S. (2013). Ever Try Teaching a Dog To Read? Implicit Theories of Reading Ability. Anthrozoos 26(3): 381-393. 
Motomura, N., Yagi, T., Ohyama, H. (2004). Animal Assisted Therapy for People with Dementia. Psychogeriatrics 4: 40-42.

Onwuegbuzie, A. J., Leech, N. L. (2006). Validity and Qualitative Research: an Oxymoron? Quality \& Quantity. Springer 41: 233-249.

Riessman, C. K., Quinney, L. (2005). Narrative in Social Work. Qualitative SocialWork. Thousand Oaks 4 (4): 391-412. Sage Publications: London.

Ritchie, E. C., Amaker, R. J. (2012). The Early Years. The Army Medical Department Journal, April-June: 5-7.

Travers, C., Perkins, J., Rand, J. ir kt. (2013). An Evaluation of Dog- Assisted Therapy for Residents of Aged Care Facilities with Dementia. Anthrozoos 26(2): 213-225.

Villalta-Gil, V., Roca, M., Gonzalez, N. ir kt. (2009). Dog-Assisted Therapy in the Treatment of Chronic Schizophrenia Inpatients. Anthrozoos 22(2): 149-159.

\section{THE BEGINNING OF CANINE THERAPY IN LITHUANIA: ONE CASE STUDY}

\section{Brigita Kreivinienė, Natalia Zukhbaya, Laura Aširovienė}

\section{Summary}

Nowadays the disciplines of medicine and special education are more likely linked to integrate in its content and methods non-traditional methods supporting positive outcomes for client. Animal assisted therapy is one of such worldwide used methods that successfully found its place in practice. Canine therapy is known for more than fifty years, the positive results of researches (Ensminger, 2010; Barker et. al., 2010; Marcus, 2011; Cipriani et. al., 2013; Travers et. al., 2013) made in geriatric settings and departments of psychiatry brought to the light that the presence of dog can have impact on various aspects of quality of life. For example, patients with dementia had a better mood and improved psychosocial functioning (Travers and etc., 2013), generalized and specific symptoms of patients with chronic schizophrenia were less observed (Villalta-Gil et. al., 2009) after meetings with dog.

USA and Great Britain has the time-longest practice of canine therapy, therefore, it is a common practice to include therapeutic dog into medical or special education team (Marcus, 2011). Barker et. al. (2010) and González-Ramírez et. al. (2013) research showed that the presence of dog can help handling with stress and therapy works as stress removal. Special education programs improved functioning of children with various disabilities (Altschiller, 2011), like children with dyslexia, cerebral palsy, autism, etc. The majority of changes occurring after the canine therapy were psychological, like the development of courage, openness to communication, better contact with peers; and functional, like the development of language, better physical functioning, etc. (Altschiller, 2011; Ensminger, 2010). 
Canine therapy is a new phenomenon in Lithuania. Currently no research were published but practical work is being done actively for the last few years. Therefore, the aim of this study is to present the very first scientific data gathered in exploratory research of canine therapy in Lithuania. Qualitative data analysis in one case study was applied. The research was conducted in Klaipeda "Medeinès" school.

Qualitative one case study was applied using different research methods: narrative and content analyses. Narrative analysis was used to analyze data gathered from educators, psychologist and mother of the child after each canine therapy session. Narrative interpretation was applied for canine therapy observation report, when each five minutes the changes of child were described. Content analysis (counting results) was used for picturing emotional scale of child prepared by psychologists.

Research results and conclusions. Research results brought to the light that ten explorative canine therapy sessions considerably increased parameters of quality of life in child and child's family. Analysis of educators' and psychologist's feedback collected after each canine therapy session revealed considerable psychosocial changes in child: the child was more open and had more courage to communicate in peer groups, verbal expression was greater and more precise, higher range of active verbal vocabulary, and child was smiling more often. Questionnaire with open questions filled by mother revealed that canine therapy increased child's better adaptation possibilities in school, also changes in physical parameters (greater appetite, activity). Report of canine therapy observation divulged that sessions were important for child's greater social development, verbal expression and cognitive development. Scale of emotional evaluation showed that canine therapy sessions have great importance in developing positive emotions. 